\title{
Identification of the Effective E-Promotional Tools on Improving Destination Brand Image
}

Nader Seyyedamiri, Communication, Media and Information Technologies (CMI), Department of Electronic Systems, Aalborg University, Copenhagen, Denmark

Ala Khosravani, Master of Tourism, Copenhagen, Denmark

\begin{abstract}
The aim of this research is to evaluate the effect of promotional tools on creating a positive destination brand image and attracting international tourists to Iran. Mixed methods were employed based on semi-structured interviews that conducted with tourism experts. The sample size determined for an infinite population and the interviewees were chosen using the snowball method. The data was analyzed by ATLAS.ti software. Reliability and validity are determined through experts and Cronbach's alpha. The sampling design for the quantitative method is accidental and by using the Cochran formula the sample of an infinite population is obtained. The sample size is 384 tourists. The collected data by questionnaires are analyzed via SPSS software. Quantitative findings indicated the most important promotional tools. Also, the quantitative analysis showed that the internet with an average value of 3/3984 ranked first. Finally, the results indicated that the more focus on using promotional tools on a tourism destination to attract more tourists.
\end{abstract}

\section{KEYWORDS}

Brand Image, Destination Image, E-Promotional Tools, International Tourist

\section{INTRODUCTION}

The tourism industry has a special significance in the world's economy and has become one of the important sources of the country's foreign exchange earnings. Through tourism industry development, also competition is expanding (Nasrallahi et al., 2013).

In addition, according to investigations, the turnover of the tourism industry in the world is beyond the turnover of other industries and it would be about two thousand billion dollars. In the process, the achievement of tourism destinations to only a percentage of the turnover leads to a yearly income of 20 million dollars (Hamidizadeh et al., 2016).

According to statistics provided by the World Tourism Organization, the ratio of input to output tourists is equal to 0.1 . The direct impact of the tourism industry, by taking $6 \%$ of world GDP, indicates that one of the 15 future jobs will be allocated to the tourism industry. Also taking into

This article, originally published under IGI Global's copyright on March 20, 2020 will proceed with publication as an Open Access article starting on January 13, 2021 in the gold Open Access journal, Journal of Global Information Management (converted to gold Open Access January 1, 2021), and will be distributed under the terms of the Creative Commons Attribution License (http://creativecommons.org/licenses/ by/4.0/) which permits unrestricted use, distribution, and production in any medium, provided the author of the original work and original publication source are properly credited. 
account indirect effects, about 10 percent of the world GDP and one of the nine future jobs will be created by the tourism industry (UNWTO, 2016).

In the twenty-first century, technological advances caused by the increase of leisure time and people spend more time on traveling. Actually, the second half of the twentieth century should be called the era of the tourism industry. In order to succeed in the tourism industry must have a suitable condition in infrastructures and attractions and also plan to attract tourists and introduce the tourist attractions of the country to international markets (Nasrallahi et al., 2013). Today, the global Internet has become a part of daily life for most people and globalization of markets is one of the major challenges that faced marketers are facing. As a result of the increased number of travel and trade in most of the countries, as well as increasing Internet connections around the world, globalization accrued (Kotler \& Armstrong, 2008).

In fact, globalization means knowing different cultures, and local culture is part of this diversity. Studying the impact of International marketing strategies' performance is not new, but the Previous research literature does not specify the methods and amount of effects of using e-marketing and promotional tools in tourism markets of Iran and in attracting international tourists to the country through the creation of the positive image of the destination.

According to Weber \& kosuta-Telisman (1991), tourism has the potential of making economic and social contributions in order to leads to countries' tourism industry growth and the success of tourism industry in different countries becomes a significant factor in economic development strategy.

Therefore tourism marketing and using suitable promotional tool is the essential matter in gaining this goal and developing the destination. These days, promoting tourism destination encounters different kinds of challenges to achieve and retain competitive advantages.

Levitt (1986), founds that destination's image marketing is the beginning of prosperous marketing; In view of the fact that tourists' images and expectations of the destination closely related to the information sources and their thought about destinations.

Hence, according to these findings, possibilities for evaluating the destination image through marketing arise.

One of the favorable scopes in the tourism literature is destination image (Gallarza, Saura, \& Calderón García, 2002).

The theory of destination image includes cognitive and an affective component. According to Gartner (1993), the notion of destination image also possesses behavioral aspect. On 1988, Gunn argued that travel experiences directly affects destination's image and concentrating on elements that have influences on destination image creation.

In order tourists choose their travel destination, they need some information about the destination and continuously searching information via the internet, satellite, television, and social media. Despite the media provides valuable information to the tourists, but the information that they gain from unofficial sources such as the advice of friends and acquaintances and others are more effective because they are not beneficiaries in advertising that destination (Nasrallahi et al., 2013).

Online and Electronic promotion is a part of online marketing and including online advertising, online branding, and direct marketing through the Internet and so on. To apply properly advertising services, proper and available Electronic promotional tools in accordance with the innovation should be used to ultimately lead to business success (Liang, Ekinci, Occhiocupo, \& Whyatt, 2013). Iran needs to compete effectively in international tourism with neighbor countries and other regions of the world in the global market. So adaptation of innovative international marketing strategies and public policies appropriate to our country is very important. Due to the fact that tourism products are intangible and can hardly assessed before use, at purchasing the intellectual involvement would be high. Tourism product has Distinctive nature and its success depends on accurate and reliable information. Therefore, in order to minimize the risk during the decision-making process, tourists must investigate and collect a variety of travel information (Abubakar \& Ilkan, 2016). 
For example, if tourists never visited a destination before, the sources of promotion have to demonstrate a positive and precise image because this would affect the destination image formation, the destination selection, and plans to revisit (Pike, 2002). Although the Internet has become one of the most popular marketing media, because of the low number of website users in some countries, the demand factor is still considered one of the problems (Lopes, 2011).

Research has shown that destination image is an influential factor and has the effect on the choice of destination for tourists. Also, the development the destination image has multi-dimensional nature and the image formation derived from several factors (Liang et al., 2013). Development of the image is under the influence of individual psychological factors and external stimulus elements (Pike, 2002). In addition, promoting the tourist destination that is a part of the process of destination image formation is dependent on the available informational resources that some of which affects decision making (Govers, Go, \& Kumar, 2007).

So tourists for gaining information using sources such as social media and unofficial sources like word of mouth, email marketing, that have more effective impacts compared to other sources (Minazzi, 2015). The media can be divided into two parts: audio media such as radio, CD, telephone, video media such as TV, satellite, images, brochures, books, magazines, the Internet and more. Brochures are advertising intermediaries in the tourism industry and have multifaceted aims to attract and convince potential tourists (Brito \& Pratas, 2015).

As a result, this study examines the impact of promotional tools on the creation of positive destination image and attracting international tourists.

\section{REVIEW OF LITERATURE}

One of the factors affecting the formation of a destination image prior to visiting is information sources used by tourists (Friaz et al, 2008). Despite that various promotional devices are available to marketing planners, the most important tools are informational data (Clarke and Middleton, 2001), and the other tools are conveyed certain information to potential tourists. In the field of the tourism industry, information resources usually help customers in making decisions and purchase of a specific destination. Middleton and Clarke believe that marketing tools are informational data, which the costs are provided from marketing budget and are designed to create awareness among existing and potential target market in order to stimulate interest and demand for products specific to tourism. These tools also make it easier for customers to buy and use (Chao, 2005). The purpose of data here is any information that has been disseminated electronically or non-electronically and unconventional information resources that are also called complementary information can be used as important tools in tourism marketing (Clarke and Middleton, 2001). This complementary information includes word of mouth publicity, ambient advertising, and transitional advertising, special advertising, etc., (Beerli and Martin, 2004). In the opinion of Middleton and Clarke (2001), the disseminated data have physical and qualitative value, for example, they are palpable can be maintained and can be shown to others. These physical characteristics attract people. On the other hand, electronic data have a powerful and complementary role and also reduce the costs of traditional marketing methods. Among electronic advertising tools, the internet advertising is among the growing tools. If a tourism destination is not on the internet websites, the business would lose many potential customers who expect to receive all tourism information from the internet. It is clearly obvious that the success of any marketer in the highly competitive tourism market cannot be possible without the use of the internet as a marketing tool. Basically tourists, in order to choose a tourism destination, need information regarding the destination. Tourists consistently collect information from mass communication media such as television, satellite, the internet, and social media. Although these sources provide valuable information to tourists, however, they would prefer to receive a considerable part of their needed information from unofficial sources such as relatives, friends, acquaintances and other people (Silverman, 1997). 
Because friends and acquaintances are not beneficiaries in promoting the destination, so their recommendations are important to most people who want to travel. Accordingly, the tourists who are traveling to foreign countries, as opinion leaders transmit their positive and negative experiences to other people who have plans to travel. (Wangenheim \& Bayon, 2004).

Researchers have indicated that word of mouth has a significant impact on reducing the consumer perceived risks in the field of service products (Wangenheim \& Bayon, 2004). Especially tourism that is a service industry benefits of word of mouth advertising. Therefore, effective factors on word of mouth advertisements and its effect on tourist behavior have to be monitored carefully. Although marketers trying hard to persuade customers, but they forget that opinion of the previous customer has more effect on decision making of the potential customer (Bruyn \& Lilien, 2008).

Most consumers trust the opinions of friends and acquaintances and family more because these views are sincere and devoid of self-interest (Podoshen, 2008). The influence of others' advice derived from three main factors: 1 . How to communicate in word of mouth advertisements is an important factor. Most of the discussion that takes place with family or friends is supporting them to perform certain behaviors. 2. Unlike the one-way communication such as advertising, word of mouth is twoway communication. Unlike the one-way communication such as advertising, advertising spoke of the people is two-way communication. Two-way communication power derived from the fact that the potential customer can ask a question, receives explanations and a result of explanations makes a decision. 3. Attributes of customer word of mouth are that people transfer their personal experiences about products and services to others (Wilklie, 1990).

Word of mouth in the final stages of the buying process is more important because it can be ensured and the results of research show only $14 \%$ of people rely on commercial advertisements (Walker, 2001). Even more interesting is that 90 percent of those trust the products or services that a family member, friend or colleague confirms (Alire, 2007).

\section{DESTINATION BRAND IMAGE}

Brand image is consumer perception of product specific characteristics which reflected of brand association in the consumer's mind (Woodward, 2000). Cognitive perceptions can appear outwardly and this category would gain more power in service products because consumers are able to rely on their perceptions of the experience that is inherently intangible and not standardized. The brand image of product or service most of the time can be a subjective phenomenon in the individual's mind (Woodward, 2000). The created image of the brand in the consumers' mind contains all details such as symptoms, products, promotions and so on.

Recalling this perception of the consumer's mind through appropriate signs becomes possible. Positive brand image reduces the perceived risk of the consumer about the brand, as well as increase the level of consumer satisfaction and loyalty. A Brand that creates a positive image in the minds of people will be easier positioning; because the brand that has a strong and positive image more easily recalled in the customer's mind (Keller, 1998).

Baloglu and McClearly have been examined the effect of stimulating factors and personal factors on the destination image. They concluded that cognitive and emotional assessments have an effect on the overall image. Also, they found that the amount of information and types of data sources (word of mouth advertising and other types) influences cognitive image, also social and psychological triggers influences one of the emotional image aspects. The results showed that there is not a significant relationship between age and emotional assessments, but there is a significant relationship between age and one of the emotional image aspects. There is also a relation between education, cognitive and emotional image.

Hosani et. al (2006), examined the relationship between destination image and destination personality. Survey results indicated that tourist's evaluation of destinations includes cognitive, emotional and character aspects. 
Chen and Tsai (2007) examined the effect of the destination image and evaluative factors on tourist behavior orientations. They concluded that behavior orientations affect the image of the destination in two ways: direct and indirect.

Martin and Del. Basque (2008), have explored destination image, cognitive-affective nature and the role of psychological factors in the image formation. The results of this study indicate that the image can include cognitive and emotional evaluation of the destination before it is visited. On the other hand, the cognitive image is more effective than the emotional image of the destination. When feelings toward a destination comply with their visit motivation, they would have the more favorable emotional image.

Qu et al. (2011), in their study entitled "The integration of branding and destination image concept" found that firstly cognitive, secondly unique part and finally emotional part of the image have the most effect on the destination image formation. The overall image as a mediator between brand associations (like unique, emotional and cognitive images) and future behavior of the tourist (like a plan to revisit the destination and recommend to others) have been approved. The purpose of marketing tourism destination is to increase awareness of the brand by creating a unique tourist destination. Brand awareness represents the embodiment of the brand in the consumers' minds. Often brand awareness has provided two levels of the brand: 1. Brand recognition; 2. Brand recall.

The image that tourists have in their mind of destinations is significant. Thus, it requires marketing and promoting of the destination to create a positive image and informing people about the tourist destination. Destination image has influence in final choice and individual behavior of the potential tourist (Chen and Tsai, 2007). Destination image marketing is the start point of successful tourism marketing because the image and expectations of visitors' travel experiences in the future will lead their thoughts to a special destination (Chao, 2005). The potential Tourist's cognitive image of the destination has an important role in destination choice. A positive image of a destination increases tourists' awareness and strengthen competitive advantage of the destination. Since the destination image is a strong motivation for excursions and leisure travels, the success or failure of it depends on the image that tourist has in the mind (Middleton and Clarke, 2001).

Therefore, to achieve successful destination marketing, tourism marketers should create an effective and relevant image being available, credible, catchy, clear and appealing. An image may change or be created in less time through marketing tools and word of mouth advertising by which an event is broadcasted. Hence, choosing appropriate and effective marketing tools to convey information and create a positive impression on the potential tourists helps a lot (Chao, 2005). Successful destination image formation is central to a fitting strategy to utilize the marketing tools. The visitor's vision of a particular destination is profoundly affected by the medium through which that destination's image is conveyed. That is why the marketers should strive to communicate this image to the potential tourists by relevant means. Cutler et al. (1999) believe that the marketing tools can help make the target market and fetch the potential tourists to a less known destination. Thus, for the successful promotion of the destination image, the marketing tools must be determined selectively (Chao, 2005). Hosting different events and occasions including meetings, exhibitions, historical events, conferences, sports events, etc. is also an effective approach to attract tourists to the respective destination. This also contributes to conceiving a positive image in the minds of the first-timers. Since there are many different alternative destinations, the first one coming across the tourists would be the brand destination appealing them the most (Candrea et al., 2010).

\section{RESEARCH METHODOLOGY}

The method used in this study is descriptive in nature and the result is applicable. Mixed methods employed based on semi-structured interviews that conducted with experts in the field of tourism. The sample size determined for infinite population and the interviewees are chosen using snowball method and the interview continues until to achieve the saturation point. Also, the qualitative data 
are analyzed by employing ATLAS.ti software. The reliability and validity of the research tools are determined through experts and Cronbach's alpha. The sampling design that used for the quantitative method is accidental or availability sampling and by using Cochran formula the sample of an infinite population is obtained. The Sample size of 384 outbound tourists is selected. The questionnaires distributed to at the hotels, sites and Imam Khomeini International Airport. The collected data are analyzed by SPSS software. Quantitative findings indicated that twelve promotional tools can be defined as the most important. Also, the quantitative analysis showed that the internet with an average value of 3/3984 ranked first and mass media with an average value of 3/3462 are ranked second.

\section{FINDINGS}

In order to identify the most effective promotional tools in promoting the brand image of Tehran, semi-structured interviews were conducted with 7 experts in the field of tourism (Table 1).

Table 1. Interview table

\begin{tabular}{|l|l|l|l|}
\hline \multicolumn{1}{|c|}{ Row } & \multicolumn{1}{|c|}{ Interviewee Code } & \multicolumn{1}{c|}{ Field of Study } & \multicolumn{1}{c|}{ Profession } \\
\hline 1 & A & Phd of Tourism & professor \\
\hline 2 & B & MA of tourism & Incoming tours manager \\
\hline 3 & C & Phd of tourism & professor \\
\hline 4 & D & MA of tourism & Marketing manager \\
\hline 5 & E & BA of tourism & Tour guide \\
\hline 6 & F & PhD of Geography & $\begin{array}{l}\text { Research Assistant of } \\
\text { Tourism Organization }\end{array}$ \\
\hline 7 & G & PhD of Geography & $\begin{array}{l}\text { President of the Tourism } \\
\text { National Organization }\end{array}$ \\
\hline
\end{tabular}

Data collected in this section of the study are arranged, and then the researcher coded the data. The stage of open coding and qualitative analysis is done by Atlas-ti software. The findings of the interviews showed that from experts point view the most important promotional tools are as seen in Table 2.

\section{QUANTITATIVE FINDINGS}

In the next stage, a questionnaire designed by the researcher according to the most important promotional tools and distributed among the study population and this section presents the effect of promotional tools on destination image of Tehran.

The findings related to this stage analyzed by using one-way ANOVA.

The findings are as follows.

Results of one-way variance analysis showed that according to sig $=000$, the assumption of differences between two variables of promotional tools and destination image is confirmed and thus there is a significant relationship between promotional tools and Iran destination image.

According to "Means Plot" graph, there is a different structurally between mean values. On the other hand, according to the amount of " $\mathrm{F}=2.537$ ", it can be inferred that promotional tools affect destination image well. The findings of this stage provided in Table 3 and Figure 1. 
Table 2. Table of most promotional tools

\begin{tabular}{|l|l|}
\hline \multicolumn{1}{|c|}{ Number } & \multicolumn{1}{|c|}{ Promotional Tool } \\
\hline 1 & Internet (websites, online news channels \\
\hline 2 & Social media (Instagram, Facebook, TripAdvisor) \\
\hline 3 & Expos (domestic, international, cultural offices outboard) \\
\hline 4 & Newspapers and tourism magazines \\
\hline 5 & brochures \\
\hline 6 & Mass media (radio, domestic and international television channels) \\
\hline 7 & Email marketing \\
\hline 8 & Familiarization tours for important people, tourists, agencies, inviting tour guides) \\
\hline 9 & Word of mouth \\
\hline 10 & Advertising campaigns \\
\hline
\end{tabular}

Table 3. Findings related to ANOVA test

\begin{tabular}{|c|c|c|c|c|c|}
\hline & Sum of Squares & Freedom Degree & $\begin{array}{c}\text { Average of } \\
\text { Squares }\end{array}$ & $\mathbf{F}$ & Significance \\
\hline Between groups & 15.011 & 34 & .441 & 2.537 & .000 \\
\hline Within groups & 57.257 & 349 & .174 & & \\
\hline Total & 72.268 & 383 & & & \\
\hline
\end{tabular}

Figure 1. ANOVA test

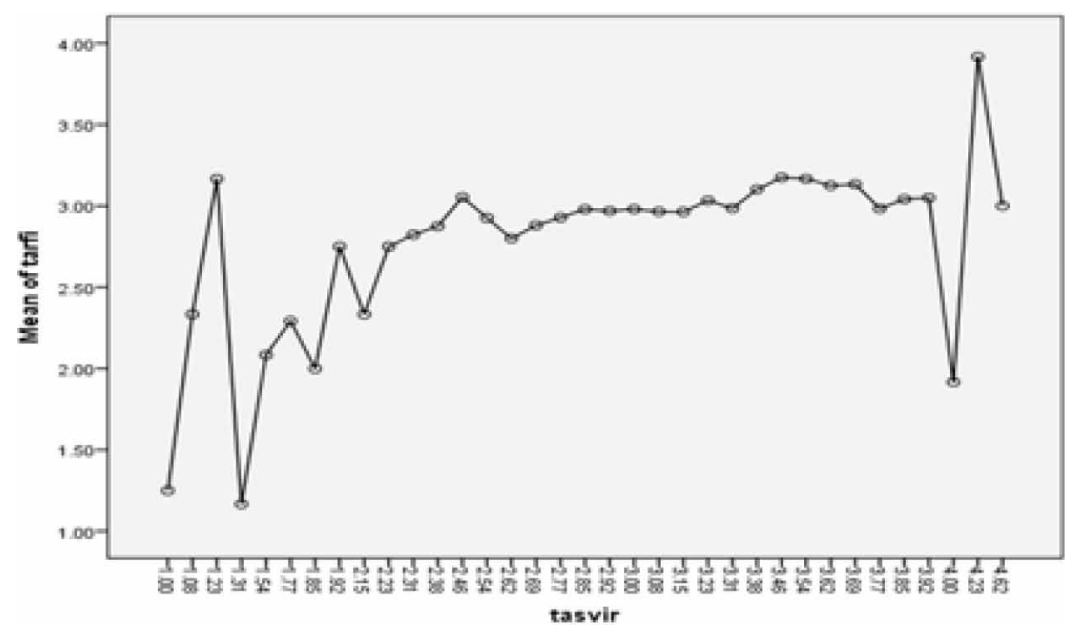

Also to investigate which kind of promotional tools has the most effect on Iran's destination image from the tourists' point of view again ANOVA test was used (Table 4). Findings showed that considering significant value promotional tools like the Internet, social media, familiarization tours, mass media, target market determination, promotional campaigns, brochures, email marketing, word of mouth advertising and newspapers have a positive impact on the destination image. 
Table 4. ANOVA table

\begin{tabular}{|c|c|c|c|c|c|c|}
\hline & & $\begin{array}{l}\text { Sum of } \\
\text { Squares }\end{array}$ & $\begin{array}{l}\text { Freedom } \\
\text { Degree }\end{array}$ & $\begin{array}{c}\text { Average of } \\
\text { Squares }\end{array}$ & $\mathbf{F}$ & Significance \\
\hline \multirow{3}{*}{ Internet } & Between groups & 27.795 & 34 & 2.817 & 2.029 & .001 \\
\hline & Within groups & 261.445 & 349 & .795 & & \\
\hline & Total & 289.239 & 383 & & & \\
\hline \multirow{3}{*}{ Social media } & Between groups & 63.913 & 34 & 1.880 & 2.368 & .000 \\
\hline & Within groups & 261.120 & 349 & .794 & & \\
\hline & Total & 325.033 & 383 & & & \\
\hline \multirow{3}{*}{ Expositions } & Between groups & 42.387 & 34 & 1.247 & 1.255 & .162 \\
\hline & Within groups & 326.764 & 349 & .993 & & \\
\hline & Total & 369.151 & 383 & & & \\
\hline \multirow{3}{*}{ Newspapers } & Between groups & 23.370 & 34 & 2.687 & 2.703 & .000 \\
\hline & Within groups & 321.605 & 349 & .978 & & \\
\hline & Total & 344.975 & 383 & & & \\
\hline \multirow{3}{*}{ Brochure } & Between groups & 43.698 & 34 & 2.285 & 2.285 & .001 \\
\hline & Within groups & 328.992 & 349 & 1.000 & & \\
\hline & Total & 372.690 & 383 & & & \\
\hline \multirow{3}{*}{ Media } & Between groups & 78.001 & 34 & 2.294 & 2.564 & .000 \\
\hline & Within groups & 294.384 & 349 & .895 & & \\
\hline & Total & 372.385 & 383 & & & \\
\hline \multirow{3}{*}{ Email marketing } & Between groups & 43.912 & 34 & 2.292 & 2.487 & .004 \\
\hline & Within groups & 285.703 & 349 & .868 & & \\
\hline & Total & 329.615 & 383 & & & \\
\hline \multirow{3}{*}{$\begin{array}{l}\text { Familiarization } \\
\text { tours }\end{array}$} & Between groups & 66.385 & 34 & 2.952 & 2.114 & .000 \\
\hline & Within groups & 303.901 & 349 & .924 & & \\
\hline & Total & 370.286 & 383 & & & \\
\hline \multirow{3}{*}{$\begin{array}{l}\text { Positive } \\
\text { international } \\
\text { destination image }\end{array}$} & Between groups & 47.808 & 34 & 1.406 & 1.133 & .285 \\
\hline & Within groups & 408.200 & 349 & 1.241 & & \\
\hline & Total & 456.008 & 383 & & & \\
\hline \multirow{3}{*}{ Word of mouth } & Between groups & 51.632 & 34 & 2.519 & 2.288 & .000 \\
\hline & Within groups & 387.761 & 349 & 1.179 & & \\
\hline & Total & 439.393 & 383 & & & \\
\hline \multirow{3}{*}{$\begin{array}{l}\text { Determination of } \\
\text { target market }\end{array}$} & Between groups & 52.764 & 34 & 1.552 & 2.109 & .000 \\
\hline & Within groups & 242.138 & 349 & .736 & & \\
\hline & Total & 294.901 & 383 & & & \\
\hline \multirow{3}{*}{$\begin{array}{l}\text { Promotional } \\
\text { campaigns }\end{array}$} & Between groups & 84.279 & 34 & 2.479 & 3.363 & .000 \\
\hline & Within groups & 242.479 & 349 & .737 & & \\
\hline & Total & 326.758 & 383 & & & \\
\hline
\end{tabular}


And finally to determine the effect's rank of each promotional tool on destination image, oneway variance analysis test was used and findings are found in Table 5. According to the "P-Value $=0.000$ " differences between the average showed a significant difference between means. So it's possible to rank the factors and according to the mean values, ranking promotional tools affecting destination image are in Table 5.

Finally to evaluate the effect of promotional tools on attracting tourists, the researcher used correlation test (Table 6). The default of this test is evaluating if the data are normal or abnormal. In order to evaluate the normality of the data Coefficients of skewness and kurtosis were evaluated. Findings showed that regarding data skewness for attracting tourists equal to the value of $-0 / 580$ and

Table 5. Ranking effective promotional tools on destination image formation

\begin{tabular}{|c|c|c|c|c|c|c|c|c|c|}
\hline Factor & Average & Rank & \multicolumn{6}{|c|}{ Grouping } & $\mathbf{n}$ \\
\hline Internet & $389 / 3$ & 1 & A & & & & & & 364 \\
\hline Media & $346 / 3$ & 2 & A & B & & & & & \\
\hline Social media & $318 / 3$ & 3 & A & B & & & & & \\
\hline Familiarization tours & $328 / 3$ & 4 & A & B & $\mathrm{C}$ & & & & \\
\hline Email marketing & $326 / 3$ & 5 & A & B & $\mathrm{C}$ & & & & \\
\hline Promotional campaigns & $315 / 3$ & 6 & & B & $\mathrm{C}$ & D & & & \\
\hline Target market determination & $054 / 3$ & 7 & & & $\mathrm{C}$ & $\mathrm{D}$ & & & \\
\hline Positive international destination image & $947 / 2$ & 8 & & & & $\mathrm{D}$ & & & \\
\hline Word of mouth & $678 / 2$ & 9 & & & & & $\mathrm{E}$ & & \\
\hline Brochures & $348 / 2$ & 10 & & & & & & $\mathrm{~F}$ & \\
\hline Attending expositions & $304 / 2$ & 11 & & & & & & $\mathrm{~F}$ & \\
\hline Magazines and newspapers & $277 / 2$ & 12 & & & & & & $\mathrm{~F}$ & \\
\hline
\end{tabular}

Figure 2. Ranking effective promotional tools on destination image formation

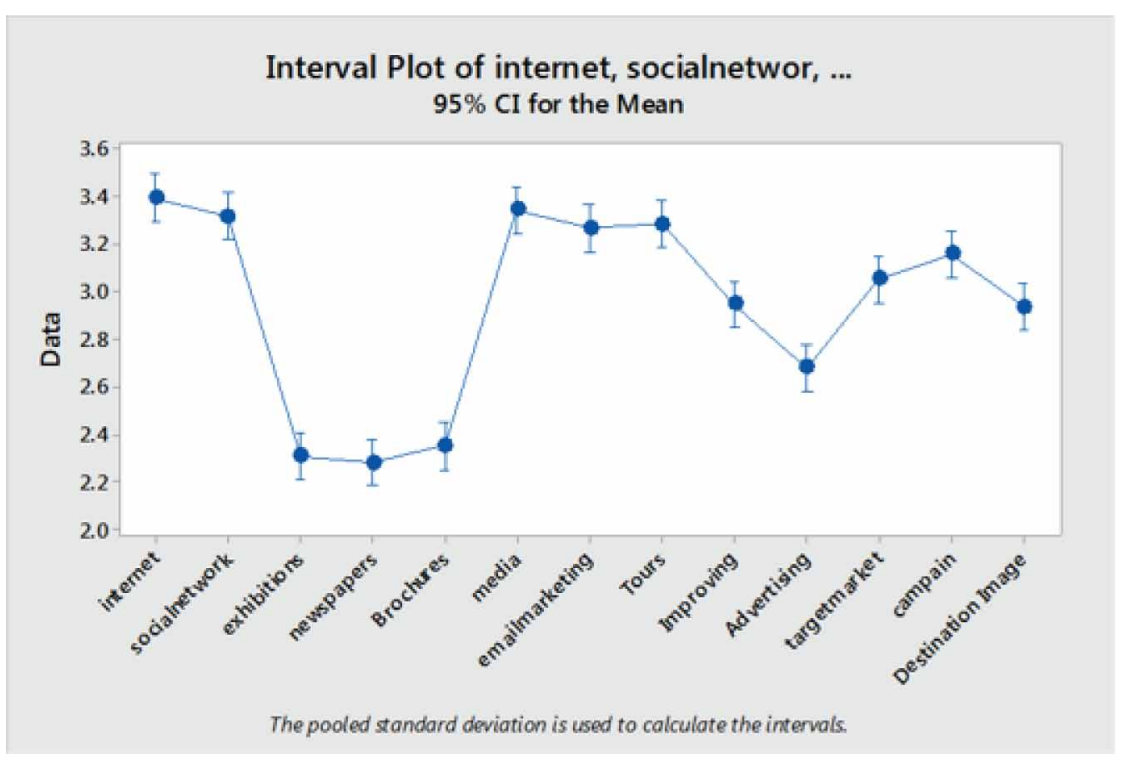


Table 6. Data normality test for choosing the suitable correlation test

\begin{tabular}{|l|l|l|l|}
\hline \multicolumn{2}{|c|}{ Population } & \multicolumn{1}{|c|}{ Tourist Attraction } & \multicolumn{1}{c|}{ Promotional Tools } \\
\hline & Acceptable & 384 & 384 \\
\cline { 2 - 4 } & Missing & 0 & 0 \\
\hline Average & 2.95 & 2.9492 \\
\hline Standard deviation & .456 & .44619 \\
\hline Variance & .208 & .199 \\
\hline Skewness & -.580 & -.454 \\
\hline The standard deviation skewness & .128 & .128 \\
\hline Kurtosis & 2.571 & .615 \\
\hline The standard deviation kurtosis & .255 & .255 \\
\hline
\end{tabular}

$-0 / 450$ for promotional tools and also positive kurtosis of both variables are abnormal, As a result Spearman test was used to examine the relationship between these two variables.

At the next stage and after the review and selection of appropriate statistical test, Spearman test findings showed that at the $99 \%$ confidence level and 0/01 error level, there is a significant relationship between promotional tools and tourist attraction. It means that promotional tools can lead to a tourist attraction. The value of this relation is equal to $0 / 188$ that shows correlations between these two variables. These findings indicate that focusing on promoting the tourist destination and spending more will lead to attracting more tourists to that destination (Table 7).

\section{Table 7. Spearman correlation test findings}

\begin{tabular}{|l|l|l|l|l|}
\hline \multicolumn{2}{|c|}{} & \multicolumn{1}{|c|}{$\begin{array}{c}\text { Attracting } \\
\text { Tourists }\end{array}$} & Promotional Tools \\
\hline \multirow{4}{*}{\begin{tabular}{|l}
\multirow{4}{|c|}{$\begin{array}{l}\text { Destination } \\
\text { image }\end{array}$} \\
Spearman test
\end{tabular}} & The correlation coefficient & 1.000 & $.188^{* *}$ \\
\cline { 2 - 5 } & Significance &. & .000 \\
\cline { 2 - 5 } & Sample & 384 & 384 \\
\cline { 2 - 5 } & \multirow{3}{*}{$\begin{array}{l}\text { Promotional } \\
\text { tools }\end{array}$} & The correlation coefficient & $.188^{* *}$ & 1.000 \\
\cline { 3 - 5 } & Significance & .000 &. \\
\cline { 3 - 5 } & Sample & 384 & 384 \\
\hline
\end{tabular}

Note: There is a significant relationship between promotional tools and attracting tourists at the error level of 0/01

\section{Contribution}

This study has a significant contribution to the knowledge. We provided remarkable information of past reasearches and data which gathered of interviees that experts in this field and also incoming tourists. These data could be used in future researches.

According to the results, the following suggestions can be made for proper planning and attracting more tourists to the destination:

1. Focuse on promotional tools for more competitive advantages in tourism destinations;

2. Considering the features of promotional tools in advertisement production and the way these tools are used to promote tourism destination; 
3. Focusing more on the role of mass media in tourism marketing;

4. The emphasise on e-promotional tools rather than traditional due to the widespread utilization of internet;

5. Planning to increase electronic infrastructures among tourism service providers.

\section{Limitations}

We hava some limitations such as, the difficulty of having access to foreign tourists, distribution of questionnaires in low season, lack of cooperation of officials at the airports, hotels and tourism sites for distributing questionnaires and difficulty of interview with tourism experts.

\section{CONCLUSION}

In order to acquire the required knowledge about the needs of the consumers and to penetrate into their perceptive image, increasing the country's reputation and fame and making use of promotional tools are important.

The results showed that positive image of the destination leads to attracting potential tourists. Also the image directly affects tourists' attitude toward travel destination. Consequently, as the internet caused to saving time and cost and also provides ease of access to information, tourists mostly take advantages of it and affect their travel choice.

Taking into consideration that owning a positive image is important for a country and has a direct impact on its tourism industry and reputation; consequently, tourism organizations should make use of appropriate promotional tools in order to create a positive image of the country. Iran needs to assess its image abroad and finding out other countries' attitudes toward Iran.

Generally people are creating a destination image in their mind through visiting the country, reading about or inquiring from friends and acquaintances. So tourism has a significant influence on creating the image of the destination among tourists. Meanwhile, tourism is one of the leading sectors of the global economy and a huge source of revenue, employment, export and tax provided by the tourism industry. Considering the benefits of the tourism industry and its role in economic development, the importance of planning for the development of tourism is more than ever required. To increase the number of tourists and revenues from them, investigating and identifying the promotional tools in order to increase international tourism demand is the basic steps in tourism planning.

On the other hand tourism industry has an important economic impact on the national and international levels and foreign exchange earnings of many countries are dependent on the tourism industry. As a result, this study aimed to investigate the impact of promotional tools to create a brand image, select travel destinations and attract international tourists to Iran, Tehran.

The existing gaps in literature are the lack of research about promoting Iran destination brand image and recognition of the most effective promotional tools for attracting tourists to Iran. In fact the development of the Internet causes a considerable impact on the tourism industry and has been cussed enormous changes in the way of communication. In order to introduce Iran as a tourist destination, create a positive image of the destination, promote and develop it, the use of promotional tools is important.

Therefore, for the development of tourism, increase in demand for travel to Iran and creating a positive brand image, tourism officials should have a better understanding of promotional tools. Mixed method used in this study, and regarding the results obtained by semi structured interviews with tourism experts, the questionnaire prepared by the researcher. The questionnaires are distributed among 384 incoming tourists in Tehran. Finally, the gathered data analyzed by SPSS software.

Results showed the most important promotional tools are as follows: Internet (websites, online news channels), social media (Instagram, Facebook, Trip Advisor), expositions (local and international), newspapers (online and printed and tourism magazines), brochures (printed and online), 
mass media (radio, television, domestic and international television channels), email marketing, familiarization tours, word of mouth, campaigns.

At the next stage the gathered data via the questionnaires analyzed and results showed that the Internet with an average of 3,3984 is the most important promotional tool and mass media with an average of 3,3462 placed second.

Finally, in order to evaluate the effectiveness of these tools on a tourist attraction, correlation test used. The findings showed that focusing on the promotion at a tourist destination and spending budget to promote the destination will attract more tourists and leads to positive destination image formation. 


\section{REFERENCES}

Abubakar, A. M., \& Ilkan, M. (2013). More adverts or more e-WOM's. Journal of Business Financial Affairs, 2(2), 129. doi:10.4172/2167-0234.1000e129

Abubakar, A. M., \& Ilkan, M. (2016). Impact of online WOM on destination trust and intention to travel: A medical tourism perspective. Journal of Destination Marketing \& Management, 5(3), 192-201. doi:10.1016/j. jdmm.2015.12.005

Alire, C. A. (2007). Word-of-mouth marketing: Abandoning the academic library ivory tower. New Library World, 108(11/12), 545-551. doi:10.1108/03074800710838272

Amine, L. S., Chao, M. C., \& Arnold, M. J. (2005). Executive insights: Exploring the practical effects of country of origin, animosity, and price-quality issues: Two case studies of Taiwan and Acer in China. Journal of International Marketing, 13(2), 114-150. doi:10.1509/jimk.13.2.114.64855

Baloglu, S., \& McCleary, K. W. (1999). A model of destination image formation. Annals of Tourism Research, 26(4), 868-897. doi:10.1016/S0160-7383(99)00030-4

Beerli, A., \& Martin, J. D. (2004). Factors influencing destination image. Annals of Tourism Research, 31(3), 657-681. doi:10.1016/j.annals.2004.01.010

Brito, P. Q., \& Pratas, J. (2015). Tourism brochures: Linking message strategies, tactics and brand destination attributes. Tourism Management, 48, 123-138. doi:10.1016/j.tourman.2014.10.013

Bruyn, A. D., \& Lilien, G. L. (2008). A multi-stage model of word of mouth influence through viral marketing. Journal of Research in Marketing, 25(February), 151-163. doi:10.1016/j.ijresmar.2008.03.004

Candrea, A. N., \& Ispas, A. (2010). Promoting tourist destinations through sport events. The case of Braşov. Revista de turism-studii si cercetari in turism, (10), 61-67.

Chao, W.-Z. (2005). Marketing tools as factors in destination image formation.

Chen, C. F., \& Tsai, D. (2007). How destination image and evaluative factors affect behavioral intentions? Tourism Management, 28(4), 1115-1122. doi:10.1016/j.tourman.2006.07.007

Cobb-Clark, D. A. (2001). Getting ahead: the determinants of and payoffs to internal promotion for young US men and women. In Worker wellbeing in a changing labor market (pp. 339-372). Emerald Group Publishing Limited. doi:10.1016/S0147-9121(01)20048-X

Echtner, C. M., \& Ritchie, J. R. (2003). The meaning and measurement of destination image. Journal of Tourism Studies, 14(1), 37.

Frías, D. M., Rodriguez, M. A., \& Castañeda, J. A. (2008). Internet vs. travel agencies on pre-visit destination image formation: An information processing view. Tourism Management, 29(1), 163-179. doi:10.1016/j. tourman.2007.02.020

Gallarza, M. G., Saura, I. G., \& Garcia, H. C. (2002). Destination image: Towards a conceptual framework. Annals of Tourism Research, 29(1), 56-78. doi:10.1016/S0160-7383(01)00031-7

Gartrell, R. B. (1988). Destination marketing: for convention and visitor bureaus. Dubuque, IA: Kendall/Hunt.

Goldsmith, R. E., Lafferty, B. A., \& Newell, S. T. (2000). The impact of corporate credibility and celebrity on consumer reaction to advertisements and brands. Journal of Advertising, 29(3), 43-55. doi:10.1080/0091336 7.2000 .10673616

Govers, R., Go, F. M., \& Kumar, K. (2007). Promoting tourism destination image. Journal of Travel Research, 46(1), 15-23. doi:10.1177/0047287507302374

Gursoy, D., \& Mccleary, W. K. (2004). An integrative model of tourists' information search behavior. Annals of Tourism Research, 34(2), 353-373. doi:10.1016/j.annals.2003.12.004

Harrison-Walker, L. J. (2001). The measurement of word-of-mouth communication and an investigation of service quality and customer commitment as potential antecedents. Journal of Service Research, 4(1), 60-75. doi:10.1177/109467050141006 
Hosany, S., Ekinci, Y., \& Uysal, M. (2006). Destination image and destination personality: An application of branding theories to tourism places. Journal of Business Research, 59(5), 638-642. doi:10.1016/j. jbusres.2006.01.001

Keller, K. L., Heckler, S. E., \& Houston, M. J. (1998). The effects of brand name suggestiveness on advertising recall. Journal of Marketing, 62(1), 48-57. doi:10.1177/002224299806200105

Khahi, M. C., Hamidizadeh, M. R., \& Ziaee, M. S. (2016). The study of tourism industry managers'authorities in promoting tourists'satisfaction. Turkish Online Journal of Design Art and Communication, 6, 2181-2195.

Kladou, S., \& Mavragani, E. (2015). Assessing destination image: An online marketing approach and the case of TripAdvisor. Journal of Destination Marketing \& Management, 4(3), 187-193. doi:10.1016/j. jdmm.2015.04.003

Kotler, P., \& Armstrong, G. (2008). Prinsip-prinsip pemasaran. Jakarta: Penerbit Erlangga.

Levitt, T. (1986). The marketing imagination: New, expanded edition. New York: Free Press.

Liang, S. W.-J., Ekinci, Y., Occhiocupo, N., \& Whyatt, G. (2013). Antecedents of travellers' electronic word-of-mouth communication. Journal of Marketing Management, 29(5-6), 584-606. doi:10.1080/026725 7X.2013.771204

Loftman, P., \& Middleton, A. (2001). Emasculating public debate and eroding local accountability: City promotion of urban development projects in Birmingham. Geographische Zeitschrift, 85-103.

Lopes, S. D. F. (2011). Destination image: Origins, developments and implications. PASOS. Revista de Turismo y Patrimonio Cultural, 9(2), 305-315.

Minazzi, R. (2015). Social media marketing in tourism and hospitality. Cham: Springer. doi:10.1007/978-3$319-05182-6$

Nasrallahi Vosta, L., Jalilvand, M. R., \& Fateh Rad, M. (2013). The effect of word of mouth on local's decision making to travel abroad.

Pike, S. (2002). Destination image analysis - a review of 142 papers from 1973 to 2000. Tourism Management, 23(5), 541-549. doi:10.1016/S0261-5177(02)00005-5

Podshen, J. S. (2008). The African-American consumer revisited: Brand loyalty, word of mouth and the effects of the black experience. Journal of Consumer Marketing, 245(4), 211-222. doi:10.1108/07363760810882407

Qu, H., Kim, L. H., \& Im, H. H. (2011). A model of destination branding: Integrating the concepts of the branding and destination image. Tourism Management, 32(3), 465-476. doi:10.1016/j.tourman.2010.03.014

Roberto, E. L., \& Kotler, P. (1989). Social marketing: Strategies for changing public behavior. New York: The Free Press.

San Martín, H., \& Del Bosque, I. A. R. (2008). Exploring the cognitive-affective nature of destination image and the role of psychological factors in its formation. Tourism Management, 29(2), 263-277. doi:10.1016/j. tourman.2007.03.012

Silverman, G. (1997). Harvesting the power of word of mouth. Potentials in Marketing, 30(9), 14-16.

UNWTO. (2016). UNWTO tourism highlights. v. Wangenheim, F., \& Bayón, T. (2004). The effect of word of mouth on services switching: Measurement and moderating variables. European Journal of Marketing, 38(9/10), 1173-1185.

Weber, S., \& Kosuta-Telisman, N. (1991). The possibilities of foreign tourism market segmentation and the evaluation of the tourism supply of SR Croatia. Academic Press.

Wilklie, W. L. (1990). Consumer Behavior. Newbury Park, CA: John and Sons Publications.

Woodward, T. (2000). Using brand awareness and brand image in tourism channels of distribution. Journal of Vacation Marketing, 6(2), 119-130. doi:10.1177/135676670000600203 
Nader Seyyedamiri is a faculty member, Faculty of Entrepreneurship. In addition, he also works as a Guest Researcher at Aalborg University of Denmark, Campus of Copenhagen. He has PhD of Marketing from University of Tehran. Nader's research area is entrepreneurial marketing and digital marketing in small and medium e-businesses, and SMEs. Nader is author of many academic articles and book in marketing and entrepreneurship. $\mathrm{He}$ is also a member of the ITS (International Telecommunication Society). Nader is consultant of marketing systems on small and medium businesses. He serves in the board of directors in several companies and established numbers of startups. 